INTERNATIONAL JOURNAL OF RESEARCHES IN BIOSCIENCES, AGRICULTURE AND TECHNOLOGY (C) VISHWASHANTI MULTIPURPOSE SOCIETY (Global Peace Multipurpose Society) R. No.MH-659/13(N)

\title{
PRESENT STATUS AND FUTURE OF SERICULTURE IN MAHARASHTRA STATE, INDIA
}

\author{
S.S.Nimgare ${ }^{1}$, U.W.Fule ${ }^{1}$ and P.M.Telkhade ${ }^{2}$ \\ ${ }^{1}$ Hutatma Rashtriya Arts and Science College, Ashti. \\ 2Arts, Commerce and Science College, Tukum, Chandrapur \\ patankar.kargi@gmail.com
}

\begin{abstract}
:
Sericulture is agro based business having great capacity of employment and rural development. Geography and weather of Maharashtra state is suitable for sericulture. So it can gives great production of silk and remarkable income, hence it can greatly minimize farmer suicide.In Maharashtra in all 22 Districts are involved in sericulture of which 18 Districts are engaged in mulberry sericulture. In India in $2014-15,74.51 \%(21,390$ metric ton $)$ Mulberry silk,8.48\% (2,434 metric ton) Tasarsilk,16.46\% (4,726 metric ton) Eri silk, $0.55 \%$ (158 metric ton) Mooga silk was produced of which 221 metric ton was contributed by Maharashtra state. In 2013-14 only 3720.25 acre area was under mulberry cultivation in which 760.97 metric ton cocoons and 111.52 metric ton silk thread was produced. In 2013-14productivitywas increased upto $204.56 \mathrm{~kg} /$ acre/yr. Total area under mulberry cultivation, total production of silk cocoons and thread and total productivity from 2004-05 to 2013-14 in Maharashtra state.
\end{abstract}

Keywords: Sericulture, Employment, Productivity, Maharashtra state

\section{Introduction:}

In West Maharashtra and Vidarbha, production of mulberry is getting importance and area of mulberry cultivation is increasing day in this region. For successful silk farming, Mulberry cultivation and silk worm rearing should be done scientifically. Silk farming is famous in Maharashtra and silk is used for threading and making silk cloth. Silk clothes have tremendous demand in Maharashtra and in other states. This demand is increasing by 16 to $20 \%$ every year. Silk farming has great capacity of self-employment. Mulberry cultivation can conserve environment as well as silk worm rearing, threading, clothing, and prevent migration of rural population to urban area.

In Vidarbha region of Maharashtra State, particularly Gadchiroli, Bhandara, Gondia and Chandrapur District tasar sericulture is carried out on Yen and Arjun trees. Specially in vidarbh (Silk and Milk) concept is held together. In this case from one acre of mulberry cultivation we can get money by selling of cocoon as well as by milk selling as branches and leaves of mulberry plant, remnants of mulberry food after eating and faeces of silkworms contain high amount of proteins and are provided as food to cattle. We can observe and study mulberry cultivation, silk worm rearing and threading combinely in State silk park on Amravati- Badnera road of Vidarbha.

In Maharashtra State 18 districts motivate mulberry sericulture while only 04 districts (Gadchiroli, Bhandara, Gondia, Chandrapur) are involved in tasar sericulture.

State directory of sericulture is at Nagpur and in all 22 district are involved in sericulture.

Weather-
Weather in all districts of Maharashtra is suitable for mulberry cultivation. While silkworm rearing needs temperature about 25280c and moisture 65-85\%.

Opportunities to self-Employment-

1) By doing mulberry cultivation, leaves and branches of mulberry can be sold to sericulture center or silk worm rearing center.

2) Sell of eggs/ seeds for silk worm rearing.

3) Rearing of silkworm larvae and is sell to other farmers.

4) Rearing of adult silkworm to produce cocoons.

5) Purchace of cocoon and separation of thread.

6) Making of silk clothes by handicrafts and by machine.

7) Colouring and designing of silk clothes.

8) Making article such as bags and other handicraft material from silk clothes.

9) Sell of silk clothes eg. Paithani Sarees, and maintainance of these business.

10) Production of equipments essential for Sericulture.

11) To run sericulture maintenance center and its quality improvement and guidance center.

\section{Observation and Discussion:}

In India in 2014-15,74.51\% (21,390 metric ton) Mulberry silk, $8.48 \% \quad(2,434$ metric ton $)$ Tasarsilk, $16.46 \%$ (4,726 metric ton) Eri silk, 0.55\% (158 metric ton) Mooga silk was produced of which 221 metric ton was contributed by Maharashtra State. In Maharashtra State,4163.75 acre area was under mulberry cultivation in 2004-05 in which 373.80 metric tonn silk cocoons and 46.73 metric ton silk thread was produced. Total productivity in 2004-05 was $89.78 \mathrm{~kg} /$ acre/yr , while in 2013-14 only 3720.25 acre area was under mulberry 
cultivation in which 760.97 metric ton cocoons and 111.52 metric ton silk thread was produced. In 2013-14 productivity was increased up to $204.56 \mathrm{~kg} / \mathrm{acre} / \mathrm{yr}$. Total area under mulberry cultivation, total production of silk cocoons and thread and total productivity from 2004-05 to 2013-14 in Maharashtra State is given in Table- 1 .

Similarly, in Maharashtra State, tasar food trees in 18866 hector area were utilized in 200910 by which 200.00 lac tasar silk cocoons and $8460 \mathrm{~kg}$. tasar silk thread was produced while in 2013-14 food plants only in6491 hector area were utilized to produce 187.16 lac tasar silk cocoons and 10199.46kg.tasar silk thread. Total area under tasar food plants cultivation, tasar cocoon, thread production and employment rate is given in Table-2. Present status of mulberry silk production in Maharashtra State is mentioned in Table-3.
From $15^{\text {th }}$ century silk production is initiated in our country but in 1949, Central sericulture board is established in India from which silk production extension progress and research was initiated and now near about 80.03 lac people are getting employment in our country.

Though silk production is going on in large quantity in India, Still 6 to 7 thousand metric ton silk thread is imported from other countries in 2014-2015. On processing, high quality silk clothes are made from these threads and then exported to about 100 other countries. In 201415 clothes of cost Rs/ 2829,87 crore are exported from India(DGCIS, Culcutta, April 2015 ) which includes mostly natural threads, clothes, readymade garments, silk carpets, and waste silk are included.

Table1 :Silk Industries Status Inmaharashtra State

\begin{tabular}{|l|l|l|l|l|l|}
\hline S.N. & Year & $\begin{array}{l}\text { Mulberry } \\
\text { cultivation } \\
\text { area (acre) }\end{array}$ & $\begin{array}{l}\text { Cocoon } \\
\text { Production } \\
\text { (metric tonn) }\end{array}$ & $\begin{array}{l}\text { Cocoon } \\
\text { Productivity } \\
\text { (Kg/acre/year) }\end{array}$ & $\begin{array}{l}\text { Thread making } \\
\text { (metric tonn) }\end{array}$ \\
\hline 1 & $2004-05$ & 4163.75 & 373.80 & 89.78 & 46.73 \\
\hline 2 & $2005-06$ & 3538.00 & 425.88 & 120.37 & 53.24 \\
\hline 3 & $2006-07$ & 6677.00 & 767.50 & 132.83 & 95.74 \\
\hline 4 & $2007-08$ & 10280.00 & 1183.70 & 115.14 & 147.96 \\
\hline 5 & $2008-09$ & 10864.00 & 1593.20 & 146.65 & 199.15 \\
\hline 6 & $2009-10$ & 9359.00 & 1743.80 & 186.96 & 218.72 \\
\hline 7 & $2010-11$ & 7335.25 & 1563.50 & 216.94 & 198.77 \\
\hline 8 & $2011-12$ & 5815.00 & 1227.81 & 211.10 & 153.40 \\
\hline 9 & $2012-13$ & 4386.10 & 700.00 & 159.60 & 87.50 \\
\hline 10 & $2013-14$ & 3720.25 & 760.97 & 204.56 & 111.52 \\
\hline
\end{tabular}

Table 2:Present Status Of Tasar Silk Productionin Maharashtra State

\begin{tabular}{|l|l|l|l|l|l|l|}
\hline S.N. & Data & Year & \multicolumn{3}{l|}{} \\
\cline { 3 - 7 } & & $\mathbf{2 0 0 9 - 1 0}$ & $\mathbf{2 0 1 0 - 1 1}$ & $\mathbf{2 0 1 1 - 1 2}$ & $\mathbf{2 0 1 2 - 1 3}$ & $\mathbf{2 0 1 3 - 1 4}$ \\
\hline 1. & Use of Tasar food tree(hectre) & 18866 & 18866 & 6015 & 8788 & 6491 \\
\hline 2. & Eggs(no.) & 558000 & 575000 & 836863 & 946575 & 838416 \\
\hline 3. & Cocoon Production(no.in lacs) & 200.00 & 168.61 & 308.65 & 243.83 & 187.16 \\
\hline 4. & Tasar thread making(Kg) & 8460.00 & 6744.00 & 12340.00 & 9753.20 & 10199.46 \\
\hline 5. & Employment Generation(Man per day) & 1269000 & 1011000 & 1851900 & 1462980 & 1529918 \\
\hline
\end{tabular}

Table 3:Present Status Of Mulb

erry Silk Production In Maharashtra State

\begin{tabular}{|l|l|l|l|l|l|l|}
\hline \multirow{2}{*}{ S.N. } & \multirow{2}{*}{ Data } & \multicolumn{2}{|c|}{ Year } & \multicolumn{2}{c|}{} \\
\cline { 3 - 7 } & & $\mathbf{2 0 0 9 - 1 0}$ & $\mathbf{2 0 1 0 - 1 1}$ & $\mathbf{2 0 1 1 - 1 2}$ & $\mathbf{2 0 1 2 - 1 3}$ & $\mathbf{2 0 1 3 - 1 4}$ \\
\hline 1. & $\begin{array}{l}\text { Farmer/Beneficiaries } \\
\text { (no.) }\end{array}$ & 6305 & 4892 & 4004 & 3218 & 3057 \\
\hline 2. & Area under Mulberry cultivation(acre) & 9359.00 & 7326.00 & 5816.00 & 4386.10 & 3720.25 \\
\hline 3. & Eggs Distribution(in lacs) & 36.81 & 30.59 & 22.85 & 12.68 & 13.53 \\
\hline 4. & Cocoon Production(no. in lacs) & $\begin{array}{l}1744.0 \\
0\end{array}$ & 1590.18 & 1227.80 & 700.03 & 760.96 \\
\hline 5. & Silk Production(metric tonn) & 18.00 & 214.25 & 153.40 & 87.50 & 111.52 \\
\hline 6. & Employment Generation(in lacs) & 46.98 & 36.78 & 29.08 & 21.93 & 18.60 \\
\hline
\end{tabular}

\section{References:}

Annual Report of central sericulture Research and Training Institute, central silk board, mysore .Indian silk, vol.47(5) 2008.

Md. Aslam (2008): Adding value. Biotech News, Vol. III(5), Pg 9.
Sericulture and Silk Industry statistics, (2003): Central silk Board, Govt of India, Bangalore.

History of Sericulture (PDF) (2010): Government of Andhra Pradesh(India), Department of sericulture. 
Bezzina Neville, (2012): "Silk production process," Sense of Nature Research.

"Silk Making. (2014): How to make." Texture silk.com.Mahatma Gandhi, 100 years, (1968): Pg 349. Silk Moth fly free (dead link) Kusuma Rajaiahs
Ahimsa project.Silk saree without killing a single silkworm, Another Article about Rajaiah and his methods.

"Down and silk,(2007): Birds and Insects, Exploited for fabric " PETA.

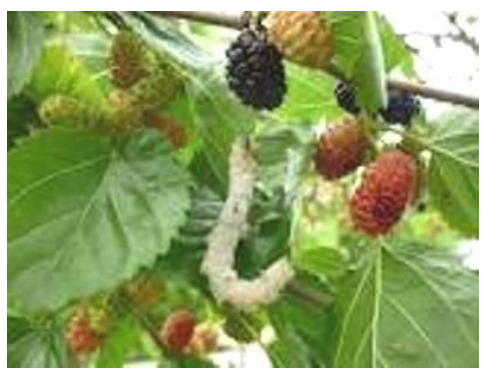

Fig.-1 : Mulberry plant with silk larva

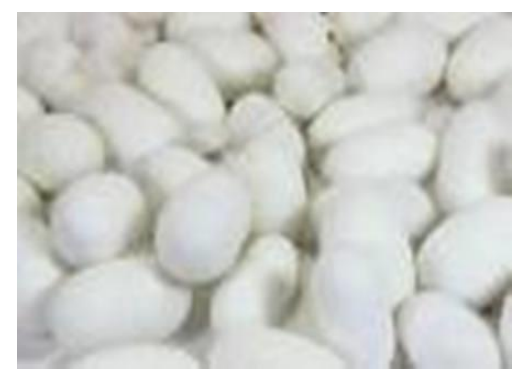

Fig.-2 : Mulberry silk cocoons

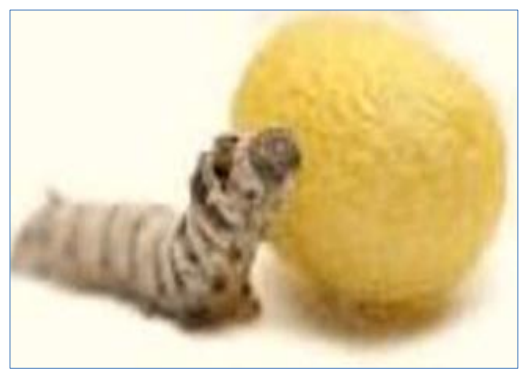

Fig.-3 : Tasar silk larva with cocoon 